\title{
OVERVIEW OF THYROID SURGERY COMPLICATIONS
}

\author{
Juraj Lukinović and Mario Bilić \\ University Department of Otolaryngology and Head and Neck Surgery, \\ Zagreb University Hospital Center
}

\begin{abstract}
SUMMARY - Introduction: The most obvious indication for thyroid surgery is malignancy, but other indications are also not rare. As with any other surgical procedure, those surgeries also carry risks which can be classified as minor or major. Discussion: In this overview, we present minor (seroma, scarring) and major complications of thyroid surgery (recurrent nerve injury, hypoparathyroidism, and bleeding). We discuss the possibilities of prevention and treatment of each of those complications. Conclusion: In recent years, thyroid surgery is becoming safer due to the development of new surgical, hemostatic, and other techniques such as intraoperative monitoring of the recurrent laryngeal nerve and parathyroid gland detection.
\end{abstract}

Key words: thyroid surgery, complications, hypocalcemia, thyroidectomy

\section{Introduction}

There are various indications for thyroid surgery. The most obvious one is the diagnosis of thyroid cancer set by fine needle aspiration biopsy, which is still the golden standard in diagnostics of thyroid nodes. The incidence of thyroid carcinoma in Croatia has been increasing in the last 15-20 years, largely due to better and more systematic diagnostics that detect even small carcinomas. Hurthle cell tumors are also an indication for at least a lobectomy, because pathohistological diagnosis is the only way of distinguishing benign from malignant lesions. Large goiters, especially when they are associated with compressive symptoms such as dysphagia, dyspnea, or hoarseness, are also usually treated surgically. Hyperthyroidism and aesthetic reasons can also sometimes be indications.

\section{History of thyroid surgery and its complications}

Thyroid surgery is a relatively new branch of surgery. It was poorly developed until the middle of the

Corresponding author: Mario Bilic, $M D, P h D$, University Department of Otolaryngology and Head and Neck Surgery, Zagreb University Hospital Center, Kišpatićeva 12, 10000 Zagreb, Croatia E-mail: mario.bilic4 zg.t-com.hr $19^{\text {th }}$ century. The opinion of great surgeons of that time, Robert Liston and Samuel Gross, was that surgical procedures on the thyroid gland are very complicated and associated with high risk, while the French Medical Society banned these operations completely in the year $1850 .{ }^{1,2}$ At the time, the mortality rate was close to $40 \% .{ }^{1}$ Thyroid surgery began to develop more rapidly as the result of improved anesthesia, infection prophylaxis, new hemostatic procedures, and surgical techniques. This also helped Theodor Kocher to lower the mortality rate of these operations to just $0.5 \%$ out of the total number of as many as 5000 thyroid procedures that he performed. The horizontal neck incision that he was using in his later years is still in use today. ${ }^{3}$

Theodor Billroth, another famous surgeon, also performed a large series of thyroidectomies at the time but with a slightly rougher surgical technique and with less regard for hemostasis. However, when comparing these two surgeons, he had much more hypocalcemias. ${ }^{2}$ In 1891, Gley hypothesized that this complication was probably due to the accidental removal of the parathyroid glands or their devascularization, so he ultimately realized that the lower thyroid artery should not be clamped at its main trunk. ${ }^{4}$

Unlike hypoparathyroidism, recurrent nerve injury was recognized as a complication much earlier, so Ko- 
cher and Billroth were both leaving the posterior part of the thyroid capsule, thus avoiding nerve damage. In the early $20^{\text {th }}$ century, surgeons started to actively search for and expose the nerve in order to minimize the risk of accidental injury. Kocher is responsible for the description of another significant complication, hypothyroidism, although he did not attribute the symptoms to a lack of thyroid hormones at the beginning. All of his total thyroidectomy patients experienced such symptoms, but most patients who underwent partial thyroidectomy did not, so he advocated only partial removal of thyroid tissue.

\section{Minor complications}

Complications can be roughly divided into milder (or minor) and more serious (or major) ones. The formation of seroma and more pronounced scarring of the wound are classified as milder complications. According to the definition, seroma is the accumulation of clear fluid that occurs as a result of exudation after trauma or surgery. ${ }^{5}$ If a minor seroma develops, it can be left untreated until it spontaneously resorbs, while aspiration or dilation of the wound under sterile conditions is suggested for larger seromas. There have only been a few studies so far that have examined the frequency of seroma formation after thyroidectomy. In general, we can say that the incidence is slightly lower when using newer coagulation devices such as an ultrasonic knife. ${ }^{6,7}$ A good preventive measure for the occurrence of seroma is certainly the installation and timely removal of the drainage of the wound.

Aesthetic results are particularly important in thyroid surgery, as patients are mostly women and sometimes young adults and the incision is in a highly visible anatomic location on the neck.

Conventional thyroidectomy, unlike rarely used endoscopic techniques, has the highest possibility of scarring, which is not only visible but also it can lead to feeling of a foreign body in the throat and difficulties with swallowing. In these cases, scar tissue is present not only in the skin but also extends across the strap muscles all the way to the thyroid cartilage, thus becoming fixed to a certain degree. Kim et al. analyzed the risk factors for hypertrophic scarring after thyroidectomy and showed that obesity, prominent sternocleidomastoid muscles, and small distance between the incision and the jugular were associated with a higher incidence of hypertrophic scars. ${ }^{8}$ Studies on hypertro- phic scarring are also rare and so are the descriptions of correction of this extensive fibrous tissue for symptomatic patients (dysphagia and foreign body sensation). $\mathrm{Z}$-plasty using a platysma flap is an example, as described by Jeon et al. ${ }^{9}$ To a certain degree, the patient can prevent scarring by massaging the scar in order to prevent fibrous fixation of deeper structures. Cremes against scarring can also be helpful.

Postoperative dysphagia is not necessarily the result of scarring, but may be caused by altered vascular supply or damage to small recurrent nerve branches that innervate the cricopharyngeal muscle. The more extensive the surgical procedure is, the more pronounced the postoperative dysphagia. It is particularly often seen after paratracheal lymph node dissection and surgical treatment for hyperthyreosis. ${ }^{10,11}$

\section{Major complications}

\section{Postoperative bleeding}

As after any other surgical procedure, bleeding and hematoma formation are also possible after thyroidectomy. Blood supply to the thyroid gland is very abundant, thus increasing the possibility of bleeding. It is not a very common complication, but consequences can be very severe and life-threatening. The bleeding usually happens after clamp and tie technique failure, poor coagulation of smaller vessels, increased blood pressure after operation, or damage to remnant thyroid tissue that was not removed. ${ }^{12}$ The incidence of bleeding is the highest in male patients, in case of a toxic goiter and after total thyroidectomy, but it is possible after any surgical intervention on the thyroid gland. ${ }^{13}$ The most common presentation of this complication is neck swelling, neck pain, skin ecchymosis, and stridor and hypoxia in more severe cases symptoms of airway obstruction such as dyspnea. The neck swelling is not always a sign of severe bleeding, as it can sometimes be caused my minor superficial bleeding just under the skin, superficial to strap muscles. But one should keep in mind that much more dangerous deep-region hematomas and bleeding may not present with large neck swelling, making this life-threatening complication harder to recognize. This is especially common if the strap muscles are completely sutured. When bleeding occurs, the pressure in this relatively small compartment can increase rapidly, causing pressure on the denuded trachea, sometimes dislocating it and leading 
to respiratory distress, stridor, and hypoxia with possible lethal consequences. Increased pressure also produces venous and lymphatic stasis in the endolarynx, causing laryngeal edema which makes endotracheal intubation during revision surgery even more difficult or even impossible. This is why hematoma formation in a deeper region of the neck is far more dangerous than in superficial ones. ${ }^{12}$ The majority of hematomas form in the first few hours after the initial surgical procedure. In an extensive study performed by Promberger et al., postoperative bleeding occurred in 336 (80.6\%) of 417 patients within the first 6 hours after surgery. ${ }^{14}$ Upon review of 6 other studies, we found that the incidence within the first 8 hours varied from $0-25 \%$ and the largest study being the one by Lacoste on more than 3000 thyroidectomies. ${ }^{15-20}$ Bleeding occurs very rarely after 24 hours. ${ }^{21}$

Postoperative hematoma occurs at a rate of approximately $0.1 \%$ to $1.1 \%{ }^{22,23}$, but in highly experienced departments that rate usually does not exceed $1 \%{ }^{24}$ Many of factors can lead to a higher likelihood of postoperative bleeding, including factors related to the patient, the surgeon, or both. Prevention should be initiated during the procedure itself, by performing precise hemostasis. Not only does this decrease the likelihood of bleeding, but also improves the chances of exact visualization and preservation of parathyroid glands and recurrent nerves. ${ }^{24}$ Conventional hemostatic methods include large vessel ligation and bipolar coagulation of smaller vessels. Bipolar coagulation is usually very efficient and relatively safe in thyroid surgery regarding the damage to the nerves and parathyroid glands. On the other hand, monopolar surgery should be avoided because of higher temperatures and much more collateral damage to the adjacent tissues. Use of ultrasonic dissection technology can also reduce intraoperative and postoperative bleeding, along with much less thermal injury of other important anatomical structures. ${ }^{25}$ Some authors proposed putting some hemostatic material directly into the wound at the end of the procedure. That was most often an oxidized cellulose mesh sheet. In a study performed in 2013, Amit did not demonstrate any significant advantage of these materials, only adding to drainage output without reducing the number of revision surgeries for hematoma. ${ }^{26}$ Prevention of deep hematomas, which can be life-threatening, can also be achieved by avoiding tight suturing of the strap muscles, as described by Terris. ${ }^{22}$
Observation for up to 24 hours is recommended for the majority of patients undergoing thyroid surgery. If hematoma develops with the symptoms of stridor and breathing difficulties, the surgical incision should be urgently reopened, draining as much hematoma as possible, and the patient must be returned to the operation room for revision by completely opening the wound and performing a precise hemostasis.

\section{Recurrent laryngeal nerve damage and dysphonia}

One of the best-known and described thyroid surgery complications is injury of the recurrent laryngeal nerve (RLN). It is a branch of the tenth cranial nerve (vagus) that supplies all the muscles of the larynx except the cricothyroid muscles. Nerves are not symmetrical in their course. The left nerve makes a loop under the aortic arch while the right nerve loops under the right subclavian artery, and after that they return to the neck. They are intimately associated with the thyroid gland during their course in the tracheoesophageal groove, and they enter the larynx at the level of the cricothyroid membrane. RLN injury most often occurs near the point of entrance to the larynx.

Immediate flaccidity of the ipsilateral vocal fold occurs in case of unilateral paralysis, along with the loss of abduction and adduction, severe dysphonia to complete paralytic aphonia, pneumophonia, and in many cases aspiration of food and drink into the trachea. ${ }^{27}$ The paralyzed vocal fold atrophies through time, causing the voice to deteriorate even more.

In the case of bilateral recurrent nerve injury, biphasic stridor, respiratory distress, and aphonia occur due to the closure of the glottis, often requiring urgent intubation or tracheostomy. The symptoms usually occur already at the time of extubation after total thyroidectomy. ${ }^{28}$

However, unilateral or bilateral RLN injury does not have to be complete. In such cases, the symptoms of unilateral or bilateral paresis occur but are milder, and their prominence depends on the extent of axon damage. There are a few main reasons for nerve damage: inadequate visualization of the nerve, anatomic variations of the course of both nerves, bleeding in the operative field, postoperative edema, or a combination of these factors.

Identifying the RLN during thyroid dissection is the gold standard in avoiding neural injury which, of course, is not always straightforward, especially in cas- 
es of large goiters, malignancy, or reoperations. ${ }^{29}$ The fact that there are many anatomic variations of its course and branching also makes the identification more difficult. RLN is a very delicate anatomic structure that can be damaged not only by cutting/transection, but also by stretching, compression, thermal injury, etc. ${ }^{30}$

Injuries can be subdivided into transient and permanent. Symptomatic injuries lasting more than one year are considered permanent. ${ }^{31}$ Transient injuries last less than 1 year but have different recovery times (usually between 4 and 6 weeks to complete recovery). ${ }^{32}$

The majority of authors still claim that the best way to prevent RLN injury is its exact dissection and identification during the procedure, while some hold the opinion that this is not necessary since the attempt to identify the whole course of the nerve in tracheoesophageal groove adds to the likelihood of stretching and compressing it, thus increasing the incidence of transitory pareses. ${ }^{33}$ Devices for intraoperative recurrent nerve monitoring can also be very helpful, especially in cases of large goiters, reoperations, malignancies, and other more complex cases. Permanent RLN injuries have been documented in $0.5 \%$ to $5.0 \%$ of patients, whereas transient injuries are observed un between $1 \%$ and $30 \%$ of patients, according to various studies. $^{34,35}$ Of course, more experienced institutions and surgeons report much less injuries of the recurrent nerve.

\section{Hypoparathyroidism}

Hypoparathyroidism is an extensively described complication of thyroid surgery. It significantly contributes to patient discomfort, lowering the quality of life, prolonging the hospital stay, and increasing the costs of treatment. There are usually four small parathyroid glands ( $80 \%$ population) in a close relationship with the thyroid gland. Three glands can be found in $1-7 \%$ of population, and $3-6 \%$ of the population has more than four parathyroid glands. Each operation can result in their direct trauma, devascularization, or their accidental removal. ${ }^{36-38}$ The etiology of transient hypoparathyroidism and hypocalcemia is still not completely understood and may be related to temporary ischemia of the parathyroid glands or to an increased release of the acute phase protein endothelin..$^{39,40}$ This transient or permanent loss of their function results in lower parathyroid hormone (PTH) lev- els, which are associated with different levels of hypocalcemia, as this hormone is crucial in maintaining calcium level homeostasis. Hypocalcemia is considered permanent if calcium levels do not normalize within 6 months (1.3-3.0\% of cases). In some cases, hypocalcemia remains asymptomatic because the decrease of calcium levels is not that severe. It can only be detected by routine calcium and PTH blood tests. In cases of more severe hypocalcemia, the following symptoms may occur: Chvostek's and Trousseau's signs, muscle cramps and paresthesia, or even ECG changes (prolonged QT interval) and neurological symptoms. Pattou et al. showed that patients were at high risk for developing permanent hypoparathyroidism if fewer than three parathyroid glands were left intact during surgery or the early serum PTH level was less than $12 \mathrm{pg} / \mathrm{mL} .{ }^{41}$ In order to assess patients for hypoparathyroidism, intact parathyroid hormone (iPTH) along with total and ionized serum calcium should be measured during the first 24 hours after surgery. As with s recurrent laryngeal nerve, the best prevention of parathyroid gland damage is proper visualization, hemostasis, and careful dissection. Use of new coagulation/dissection devices also helps in their preservation, lowering the thermic effect on adjacent tissue. $^{42,43}$ Hypocalcemia is treated by administering supplemental calcium, usually in form of carbonate and supplements of vitamin D. Parenteral calcium gluconate is usually added to the treatment in high-risk and symptomatic patients with low PTH and calcium levels. In selected cases where this therapy is not efficient enough, PTH can be administered in form of an injection, improving calcium levels. This treatment was approved by the FDA in 2015.

\section{References}

1. Dorairajan N, Pradeep PV. Vignette thyroid surgery: a glimpse into its history. Int Surg 2013;98(1):70-75. doi: 10.9738/ CC185.1.

2. Dadan J, Nowacka A. A journey into the past- the history of thyroid surgery. Wiad Lek 2008;61(LXI):88-92.

3. Becker WF. Presidential address: pioneers in thyroid surgery. Ann Surg 1977;185(5):493-504. doi: 10.1097/00000658197705000-00001.

4. Kocher T. In: Textbook of Operative Surgery. $2^{\text {nd }}$ ed. Black C, editor. Stiles HJ; London: 1985,99-105. doi: 10.9738/CC185.1

5. Poudel DR, Giri S, Pathak R, Morsey M, Alsafwah S. Late onset seroma post-thymectomy presenting as cardiac tampon- 
ade. J Community Hosp Intern Med Perspect 2015;5(3): 27459. DOI: 10.3402/jchimp.v5.27459

6. Sanabria A, Carvalho AL, Silver CE. Routine drainage after thyroid surgery- a meta-analysis. J. Surg. Oncol 2007;96:273280. doi: $10.1002 /$ jso. 20821.

7. Ramouz A, Rasihashemi SZ, Daghigh F, Faraji E, Rouhani S. Predisposing factors for seroma formation in patients undergoing thyroidectomy: Cross-sectional study. Ann Med Surg (Lond) 2017;23:8-12. doi: 10.1016/j.amsu.2017.09.001.

8. Kim JH, Sung JY, Kim YH, et al. Risk factors for hypertrophic surgical scar development after thyroidectomy. Wound Repair Regen 2012;20(3):304-10. doi: 10.1111/j.1524-475X.2012. 00784.x.

9. Jeon MK, Kang SJ, Sun H. Platysma flap with z-plasty for correction of post-thyroidectomy swallowing deformity. Arch Plast Surg 2013;40(4):425-432. doi: 10.5999/aps.2013.40. 4.425 .

10. Lombardi CP, Raffaelli M, D'Alatri L, et al. Voice and swallowing changes after thyroidectomy in patients without inferior laryngeal nerve injuries. Surgery 2006;140(6):1026-1034. doi: 10.1016/j.surg.2006.08.008.

11. Hillenbrand A, Cammerer G, Dankesreiter L, Lemke J, Henne-Bruns D. Postoperative swallowing disorder after thyroid and parathyroid resection. Pragmat Obs Res 2018;9: 63-68. doi: 10.2147/POR.S172059.

12. Lee HS, Lee BJ, Kim SW, et al. Patterns of Post-thyroidectomy Hemorrhage. Clin Exp Otorhinolaryngol 2009;2:72-7. doi: 10.3342/ceo.2009.2.2.72

13. Promberger R, Ott J, Kober F, et al. Risk factors for postoperative bleeding after thyroid surgery. Br J Surg. 2012;99(3):373-9. doi: 10.1002/bjs.7824.

14. Prgomet D, Bilić M, Kovac L, Hutinec Z, Topić I. Locally invasive papillary thyroid cancer--our experience. Lijec Vjesn. 2012 Sep-Oct;134(9-10):266-70. Croatian

15. Lo Gerfo P. Local/regional anesthesia for thyroidectomy: evaluation as an outpatient procedure. Surgery 1998; 124: 975-8.

16. Samson PS, Reyes FR, Saludares WN, Angeles RP, Francisco RA, Tagorda ER Jr. Outpatient thyroidectomy. Am J Surg 1997; 173: 499-503. doi: 10.1016/s0002-9610(97)00019-6.

17. Lacoste L, Gineste D, Karayan J, et al. Airway complications in thyroid surgery. Ann Otol Rhinol Laryngol 1993;102:441-6. doi: 10.1177/000348949310200607.

18. Schwartz AE, Clark OH, Ituarte P, Lo Gerfo P. Therapeutic controversy: Thyroid surgery the choice. J Clin Endocrinol Metab 1998;83:1097-105. doi: 10.1210/jcem.83.4.4740-1.

19. Hurtado-López LM, Zaldivar-Ramirez FR, Basurto Kuba E, et al. Causes for early reintervention after thyroidectomy. Med Sci Monit 2002; 8: CR247-50.

20. Abbas G, Dubner S, Heller KS. Re-operation for bleeding after thyroidectomy and parathyroidectomy. Head Neck 2001;23: 544-6. doi: 10.1002/hed.1076

21. Shaha AR, Jaffe BM. Practical management of post-thyroidectomy hematoma. J Surg Oncol 1994;57:235-8. doi: 10.1002/ jso.2930570406.
22. Materazzi G, Ambrosini CE, Fregoli L, et al. Prevention and management of bleeding in thyroid surgery. Gland Surg 2017; 6(5): 510-515. Gland Surg. 2017Oct;6(5):510-515. doi: 10.21037/gs.2017.06.14

23. Terris DJ, Snyder S, Carneiro-Pla D, et al. American Thyroid Association statement on outpatient thyroidectomy. Thyroid 2013;23:1193-202. doi: 10.1089/thy.2013.0049.

24. Reeve T, Thompson NW. Complications of thyroid surgery: how to avoid them, how to manage them, and observations on their possible effect on the whole patient. World J Surg 2000; 24:971-5. doi: 10.1007/s002680010160.

25. Prgomet D, Janjanin S, Bilić M, et al. A prospective observational study of 363 cases operated with three different harmonic scalpels. Eur Arch Otorhinolaryngol. 2009;266(12): 1965-70.

26. Amit M, Binenbaum Y, Cohen JT, et al. Effectiveness of an oxidized cellulose patch hemostatic agent in thyroid surgery: a prospective, randomized, controlled study. J Am Coll Surg 2013;217:221- 5. doi: 10.1016/j.jamcollsurg.2013.03.022.

27. Crumley RL. Unilateral recurrent laryngeal nerve paralysis. J Voice. 1994;8(1):79-83. doi: 10.1016/s0892-1997(05)80323-6.

28. Sanapala A, Nagaraju M, Rao LN, Nalluri K. Management of bilateral recurrent laryngeal nerve paresis after thyroidectomy. Anesth Essays Res. 2015;9(2):251-253. doi: 10.4103/02591162.152419.

29. Steurer M, Passler C, Denk DM, et al. Advantages of recurrent laryngeal nerve identification in thyroidectomy and parathyroidectomy and the importance of preoperative and postoperative laryngoscopic examination in more than 1000 nerves at risk. Laryngoscope 2002; 112: 124-33. doi: 10.1097/00005537200201000-00022.

30. Rosato L, Avenia N, Bernante P, et al. Complications of thyroid surgery: analysis of a multicentric study on 14,934 patients operated on in Italy over 5 years. World J Surg 2004; 28: 271-6. doi: 10.1007/s00268-003-6903-1.

31. Stager SV. Vocal fold paresis: etiology, clinical diagnosis and clinical management. Curr Opin Otolaryngol Head Neck Surg 2014; 22: 444-9. doi: 10.1097/MOO.0000000000000112.

32. Joliat GR, Guarnero V, Demartines N, Schweizer V, Matter $M$. Recurrent laryngeal nerve injury after thyroid and parathyroid surgery: Incidence and postoperative evolution assessment. Medicine (Baltimore) 2017;96(17):e6674. doi: 10.1097/ MD.0000000000006674.

33. Zakaria HM, Al Awad NA, Al Kreedes AS, et al. Recurrent laryngeal nerve injury in thyroid surgery. Oman Med J. 2011; 26(1):34-38. doi: 10.5001/omj.2011.09.

34. Bergenfelz A, Jansson S, Kristoffersson A, et al. rrComplications to thyroid surgery: results as reported in a database from a multicenter audit comprising 3,660 patients. Langenbecks Arch Surg 2008;393:667-73. doi: 10.1007/s00423-008-0366-7.

35. Jeannon JP, Orabi AA, Bruch GA, et al. Diagnosis of recurrent laryngeal nerve palsy after thyroidectomy: a systematic review. Int J Clin Pract 2009;63:624-9. doi: 10.1111/j.1742-1241. 2008.01875.x 
36. Mejia MG, Gonzalez-Devia D, Fierro F, et al. Hypocalcemia posthyroidectomy: prevention, diagnosis and management. J Transl Sci 2018;4:7. doi: 10.15761/JTS.1000212

37. Tredici P, Grosso E, Gibelli B, Massaro MA, Arrigoni C, Tradati N. Identification of patients at high risk for hypocalcemia after total thyroidectomy. Acta Otorhinolaryngol Ital 2011; 31(3):144-148.

38. Abboud B, Sargi Z, Akkam M, et al. Risk factors for post thyroidectomy hypocalcemia. J Am Surg. 2002;195:456-461. doi: 10.1016/s1072-7515(02)01310-8.

39. Radivojević RC, Prgomet D, Markesić J, Ezgeta C. Hypocalcaemia after thyroid surgery for differentiated thyroid carcinoma: preliminary study report. Coll Antropol. 2012;36 Suppl 2:73-78.

40. Nomura K, Yamashita J, Ogawa M. Endothelin -1 is involved in the transient hypoparathyroidism seen in patients under- going thyroid surgery. Journal of Endocrinology 1994;143(2): 343-351.

41. Pattou F, Combemale F, Fabre S, et al. Hypocalcemia following thyroid surgery: incidence and prediction of outcome. World J Surg 1998;22(7):718-724. doi: 10.1007/s002689900459.

42. Grabovac S, Prgomet D, Janjanin S, Hadzibegović AD. Usporedba vrijednosti paratiroidnog hormona pri operacijama stitne zlijezde ultrazvucnim rezacem i konvencionalnim metodama [Parathyroid hormone values in thyroid gland surgeries by harmonic scalpel and by conventional methods]. Lijec Vjesn. 2013;135(11-12):306-310. Croatian

43. Kusić Z, Prgomet D. Karcinom štitne i doštitne žlijezde. In: Prgomet D. Tumori glave i vrata. Zagreb, Medicinska naklada. 2019. p. 262-73.

Sažetak

\section{PREGLED KOMPLIKACIJA KIRURŠKIH ZAHVATA NA ŠTITNJAČI}

\section{Juraj Lukinović i Mario Bilić}

Uvod: Najočitija indikacija za kirurški zahvat na štitnjači je zloćudna novotvorina, ali nisu rijetke ni druge indikacije. Kao kod svake druge operacije i ovdje su mogući određeni rizici, koji se mogu podijeliti na blaže i teže. Rasprava: u ovom pregledu predstavljamo blaže (serom, ožiljke i disfagiju) i teže komplikacije kirurgije štitnjače (krvarenje, ozljeda povratnog živca i hipoparatiroidizam). Opisane su mogućnosti prevencije te liječenja svake pojedine komplikacije. Zaključak: u posljednje vrijeme kirurgija štitnjače postaje sve sigurnija, uz uvođenje novijih metoda hemostaze, kao i ostalih metoda poput intraoperativnog monitoringa povratnog živca i detekcije paratiroidnih žlijezda.

Ključne riječi: kirurgija štitnjače, bipokalcemija, komplikacije, tiroidektomija 